\title{
PEMAHAMAN TERHADAP RADIASI ALAM DAN PROTEKSI RADIASI PADA WARGA BUMI MAS CISEENG BLOK B5/05 KELURAHAN KURIPAN KECAMATAN CISEENG KAB BOGOR
}

\author{
Muhammad Irsal", Mahfud Edy Widiatmoko, Wahyu Hidayat \\ ${ }^{1}$ Poltekkes Kemenkes Jakarta 2 Jurusan Teknik Radiodiagnostik dan Radioterapi, Jakarta \\ Email: muhammad.irsal@poltekkesjkt2.ac.id
}

\begin{abstract}
ABSTRAK
Kesadaran dan persepsi telah menjadi masalah kesehatan publik dan lingkungan selama setidaknya dua dekade terakhir, sehingga diperlukan kesadaran dan pemahaman masyarakat terhadap pengetahuan tentang radiasi alam dan upaya proteksi radiasi yang bisa dilakukan. Metode dengan pemberian pemahaman yang dilakukan dengan penyuluhan menggunakan media poster dan ceramah interaktif, disertai dengan pemberian kuisioner pre-post test untuk mengukur pemahaman warga terhadap radiasi dan upaya proteksi yang dapat dilakukan. Kemudian data yang diperoleh akan uji menggunakan SPSS 26 untuk mengetahui apakah terjadi perubahan pemahaman setelah pemberian penyuluhan kepada warga dengan uji wilcoxon. Hasil setelah penyuluhan pengetahuan warga mengalami meningkat $92 \%$ untuk indikator pengertian, pemanfaatan dan efek radiasi, sedangkan $97 \%$ untuk indikator proteksi radiasi dengan antioksidan. Dari hasil uji wilcoxon nilai $\mathrm{p}<0,001$ oleh karena itu bisa dikatakan bahwa kegiatan penyuluhan tentang radiasi dan upaya proteksi dapat mempengaruhi tingkat pemahaman warga.
\end{abstract}

Kata kunci: Penyuluhan, Proteksi radiasi, Radiasi alam

\begin{abstract}
Awareness and perception have become a public health and environmental problem for at least the last two decades, so public awareness and understanding of knowledge about natural radiation and radiation protection efforts are needed. The method by providing understanding is carried out by counseling using posters and interactive lectures, accompanied by the provision of pre-post test questionnaires to measure residents' understanding of radiation and the protection efforts that can be done. Then the data obtained will be tested using SPSS 26 to find out whether there is a change in understanding after providing counseling to residents with the Wilcoxon test. The results after the community knowledge counseling increased by $92 \%$ for indicators of understanding, utilization, and effects of radiation, while $97 \%$ for indicators of radiation protection with antioxidants. From the results of the Wilcoxon test, the p value $<0.001$ therefore it can be said that counseling activities about radiation and protection efforts can affect the level of understanding of the residents.
\end{abstract}

Keywords: counseling, radiation, radiation protection 


\section{PENDAHULUAN}

Manusia terkena paparan radiasi alam setiap hari dari radiasi kosmik dan radiasi terestrial terutama dari radionuklida primordial di kerak bumi yaitu uranium dan thorium beserta peluruhannya (Alatas et al., 2012). Jumlah radionuklida yang terserap masuk kedalam tubuh melalui beberapa jalur seperti makanan, debu yang terhirup melalui paru-paru dan melalui kulit (Feydri Ferdita Dera, Sri Suryani, Bualkar Abdullah, n.d.). Data United National Scientific Committee on the Effect of Atomic Radiation (UNSCEAR) Tahun 2000 menyatakan bahwa lebih 85\% kontribusi sumber radiasi berasal dari alam dan $15 \%$ berasal dari sumber radiasi buatan (suriza putri). Radionuklida ${ }^{40} \mathrm{~K},{ }^{226} \mathrm{Ra},{ }^{232} \mathrm{Th}$ dan ${ }^{238} \mathrm{U}$ merupakan sumber utama NORM (Naturally Occurring Radioactive Material). Konsentrasi radionuklida tersebut bervariasi tergantung dari struktur geologi daerah lokasi pengukuran (Wahyudi, Syarbaini, \& Kusdiana, 2014)(Hutabarat, 2018). Nilai konsentrasi ${ }^{238} \mathrm{U}$ dan ${ }^{226} \mathrm{Ra}$ yang tidak terdeteksi, berbeda dengan unsur ${ }^{238} \mathrm{U}$, unsur ${ }^{226} \mathrm{Ra}$ mudah larut dalam air, sehingga unsur ini mudah masuk ke tubuh melalui mulut, sekitar 30\% unsur 226Ra akan terserap ke dalam organ tubuh dan akan diekskresi dalam beberapa yaitu 95-98\% dikeluarkan lewat feces dan 2-5\% lewat urin. Itulah sebabnya, konsentrasi ${ }^{226} \mathrm{Ra}$ jauh lebih rendah dari ${ }^{238} \mathrm{U}$. Waktu paruh efektif ${ }^{226} \mathrm{Ra}$ kurang lebih 4,5 tahun pada tulang dan 900 hari pada seluruh tubuh (Feydri Ferdita Dera, Sri Suryani, Bualkar Abdullah, n.d.).

Dari hasil studi oleh Pande Mande Udiyana, 2003. Pengukuran paparan radiasi pada jenis penggunaan lahan di pulau jawa, dimana hasil tertinggi untuk pertanian dengan hasil ukur sebesar $14,99 \mu \mathrm{R} /$ jam dengan rata-rata paparan 5,24 $\pm 3,94$. Sedang untuk paparan radiasi terendah pada daerah hutan 3,24 $\mu \mathrm{R} /$ jam dengan rata-rata 3,02 $\pm 0,64 \mu \mathrm{R} /$ jam (Pande, n.d.). Selain itu berdasarkan studi yang dilakukan oleh Azhari dkk, 2019. diketahui bahwa konsentrasi aktivitas radon pada daerah pegunungan di kabupaten bandung barat, rata-rata kurang dari standar EPA dan WHO, dengan dosis efektif menunjukkan nilai yang tidak signifikan. Hal yang perlu diperhatikan adalah dalam pada penggunaan sumber air tanah oleh karena kandungan materi non granitik terdapat kadar radon alami yang kecil. Nilai radon dalam air mungkin tidak berdampak langsung pada kesehatan, namun konsumsi pada jangka panjang memungkinkan untuk terendapkan di dalam struktur tulang dan gigi (Azhari Azhari, Susilo, Bintarsih, Lubis, \& Sitam, 2019).

Studi oleh wahyudi dkk, 2019. Bahwa terdapat pengaruh radiasi alam yang berasal dari kondisi geologi dan sistem ventilasi serta bahan bangunan dinding rumah. Rendahnya konsentrasi radioaktivitas bahan bangunan juga mempengaruhi rendahnya konsentrasi radon di dalam rumah. Pemakaian beton ringan atau hebel dapat menurunkan konsentrasi radon di dalam ruangan (Wahyudi, Kusdiana, Wiyono, \& Iskandar, 2019). Nilai laju dosis efektif pada sampel material bangunan semen, gipsum dan pasir. Dimana Laju dosis efektif paling besar terdapat pada sampel pasir yaitu $0,243 \mu \mathrm{Sv}$. Hal ini menunjukkan bahwa seluruh sampel memiliki laju dosis efektif dibawah nilai batas yang ditentukan oleh International commision of Radiogical Protection (ICRP) yaitu $1 \mathrm{mSv}$, sehingga dapat disimpulkan seluruh material bangunan semen, gipsum dan pasir yang diuji tidak memiliki dampak radiologi yang signifikan khususnya pada sistem pernapasan melalui udara yang terhirup (Safitri, Setiawati, \& Wijaya, 2017).

Radiasi pada dosis serendah berapapun dapat menimbulkan efek kesehatan karena sebuah kejadian ionisasi dapat menimbulkan kerusakan pada DNA. Dosis kecil, $10-100 \mathrm{mSv}$, meningkatkan laju latar kerusakan DNA sekitar 1\% yang terjadi secara alamiah. Tidak diragukan lagi bahwa tidak ada dosis atau laju dosis radiasi yang aman dalam hal menimbulkan efek pada manusia. Sejumlah pendekatan fisik dan biologik telah dilakukan untuk menggambarkan batasan dosis dan laju dosis rendah. Dari aspek mikro dosimetri, dosis rendah adalah dibawah $1 \mathrm{mGy}$. Sedangkan dari radiobiologi, sekitar $20 \mathrm{mGy}$ adalah dosis rendah. Studi epidemiologi menyatakan bahwa dosis rendah adalah dalam orde $200 \mathrm{mGy}$, berapapun besar laju dosisnya. Sedangkan studi induksi tumor 
pada hewan percobaan menyarankan bahwa laju dosis sekitar $0,1 \mathrm{mGy} / \mathrm{menit}$ adalah rendah, berapapun besar dosis totalnya (Alatas, 2003). Hal ini dikarenakan adanya risiko yang ditimbulkan oleh radiasi pengion alam terhadap kesehatan dan dalam jangka panjang dan pada akhirnya akan berdampak pada kualitas hidup (Quality of Life/QoL). Kesadaran dan persepsi telah menjadi masalah kesehatan publik dan lingkungan selama setidaknya dua dekade ini tentang bahaya dan manfaatnya (A. Azhari, Susilo, \& Sitam, 2019), sehingga diperlukan kesadaran dan pemahaman masyarakat terhadap pengetahuan bahaya radiasi sebagai upaya proteksi radiasi. oleh karena itu kami Tim pengabdian masyarakat Poltekkes Kemenkes Jakarta 2 jurusan teknik radiodiagnostik dan radioterapi memberikan pemahaman kepada warga Bumi Mas Ciseeng Blok B5/05 Kelurahan Kuripan Kecamatan Ciseeng Kab Bogor tentang radiasi alam dan proteksi radiasi dengan mengkonsumsi antioksidan.

\section{METODOLOGI PENELITIAN}

Metode dilakukan dengan pemberian penyuluhan menggunakan media poster dan ceramah interaktif seperti yang ditunjukan pada Gambar 1, disertai dengan pemberian kuesioner pre-post test untuk mengukur pemahaman masyarakat terhadap radiasi alam dan upaya proteksi radiasi dengan indikator ditunjukkan pada tabel 1. Subjek data merupakan warga Bumi Mas Ciseeng Kelurahan Kuripan Kecamatan Ciseeng Kab Bogor yang mana pada saat dilakukan kegiatan penyuluhan masih dalam pemberlakuan pembatasan kegiatan masyarakat (PPKM) oleh karena masih dalam kondisi pandemik COVID-19, sehingga peserta yang hadir dibatasi dan warga yang datang hanya warga laki-laki saja. Data yang diperoleh akan dilakukan uji menggunakan SPSS 26 untuk uji validitas dan reliabilitas, kemudian untuk mengetahui apakah pemahaman warga terjadi perubahan setelah dilakukan penyuluhan maka dilakukan uji wilcoxon.

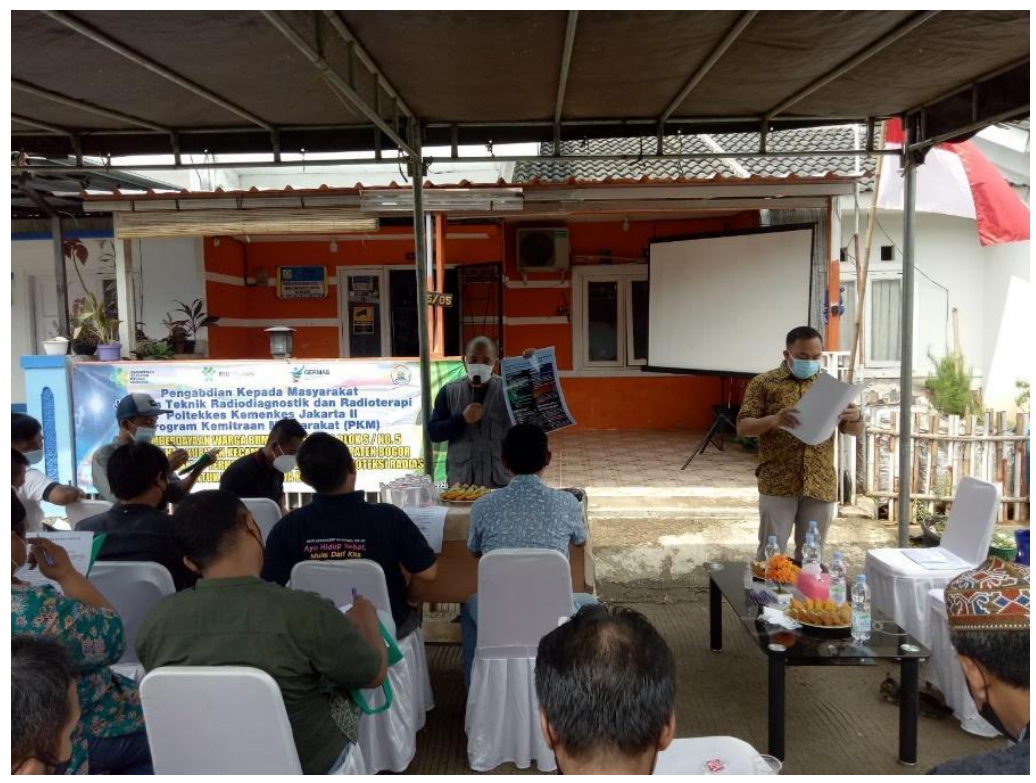

Gambar 1. Kegiatan penyuluhan

Tabel 1. Variabel kuisioner

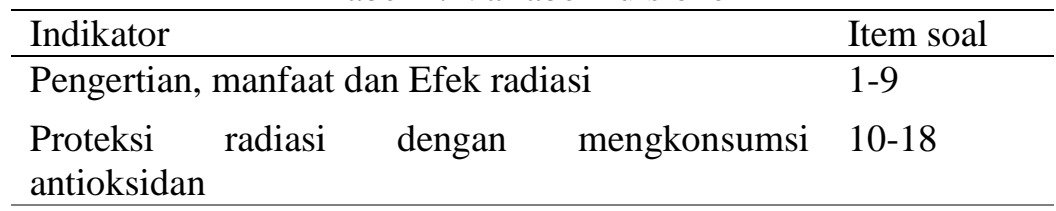




\section{HASIL DAN PEMBAHASAN}

Berdasarkan hasil data peserta yang mengikuti kegiatan penyuluhan adalah 20 orang, diperoleh jumlah usia diantara 30-65 Tahun dengan riwayat pendidikan mayoritas SMA yang seperti yang ditunjukan pada Gambar 2. Agar dapat dilakukan pengukuran maka dibuat evaluasi kegiatan dengan memberikan kuesioner pre-post test dengan terlebih dahulu melakukan uji valid dan reliabilitas untuk mengetahui apakah pertanyaan-pertanyaan yang diberikan dalam kuesioner dapat digunakan untuk mengetahui tingkat pemahaman warga perumahan ciseeng mas yang ditunjukan pada tabel 2.

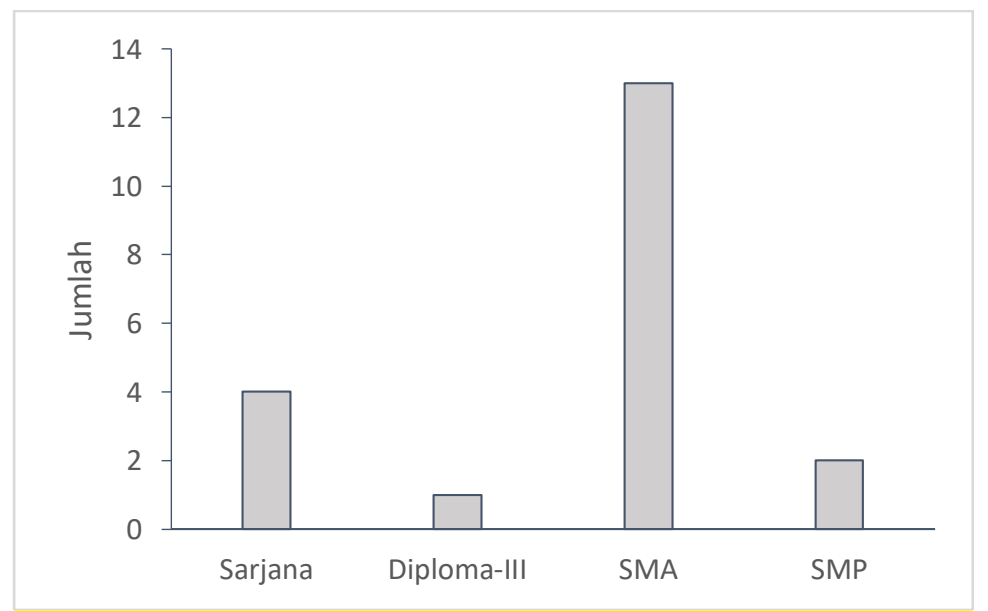

Gambar 2. Riwayat pendidikan

Tabel 2. Uji reliabilitas variabel kuesioner

\begin{tabular}{lllll}
\hline Variabel & Pertanyaan & $\begin{array}{l}\text { Nilai r- } \\
\text { hitung }\end{array}$ & $\begin{array}{l}\text { Nilai } \\
\text { r-tabel }\end{array}$ & Keterangan \\
\hline Pengertian, pemanfaatan & P1 & 0,131 & 0,468 & Valid \\
dan efek radiasi & P2 & 0,384 & Valid \\
& P3 & 0,245 & Valid \\
& P4 & 0,052 & Valid \\
& P5 & 0,660 & Valid \\
& P6 & 0,523 & Valid \\
Proteksi radiasi dengan & P1 & 0,333 & Valid \\
konsumsi antioksidan & P1 & 0,212 & Valid \\
& P1 & 0,734 & Valid \\
& P12 & 0,664 & Valid \\
& P13 & 0,424 & Valid \\
& P14 & 0,508 & Valid \\
& P15 & 0,417 & Valid \\
& P16 & 0,010 & Valid \\
& P17 & 0,245 & Valid \\
& P18 & 0,577 & Valid \\
& & & Valid \\
\hline
\end{tabular}

Berdasarkan nilai hasil persentasi pre-post test yang telah dilakukan dengan pemberian kuisioner yang terdiri dari 2 variabel indikator didapatkan terjadi perbedaan nilai pre-post test yang 
ditunjukan pada Gambar 3 dan 4. Hal ini menunjukan bahwa terjadi perubahan pemahaman pada saat dilakukan penyuluhan, dimana hasil menunjukan terjadi perbedaan nilai dengan hasil setelah penyuluhan mengalami $92 \%$ untuk indikator pengertian, pemanfaatan dan efek radiasi, sedangkan 97\% untuk indikator proteksi radiasi dengan antioksidan.

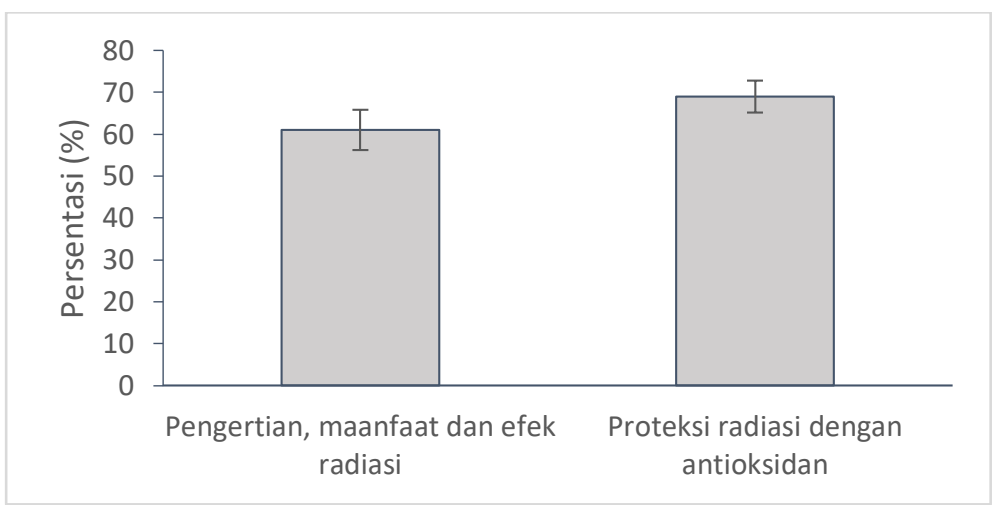

Gambar 3. Persentase pre test

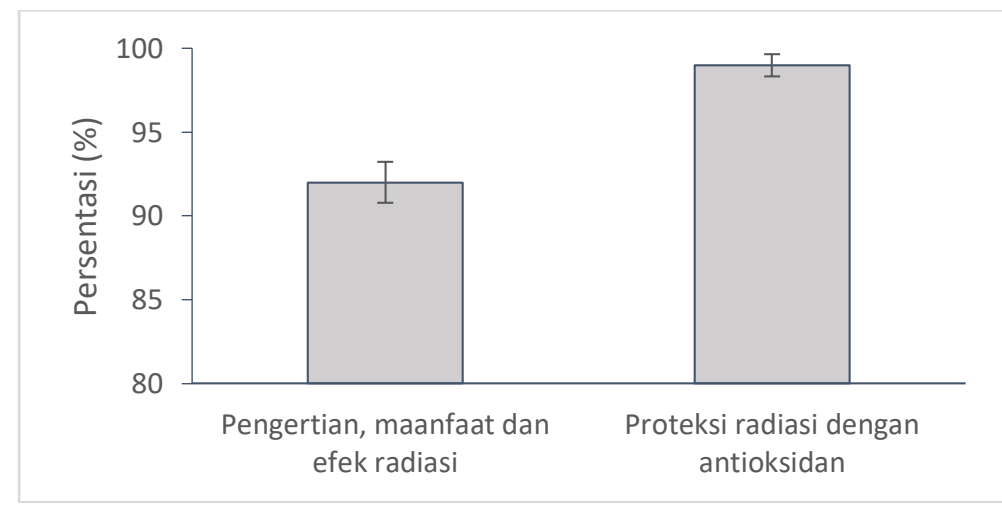

Gambar 4. Presentasi post test

Kemudian dilakukan uji normalitas dengan menggunakan shapiro-wilk dengan hasil uji ditunjukan pada tabel 3. setelah itu mengetahui apakah terjadi perubahan dengan pemahaman warga setelah penyuluhan maka hasil kuesioner pre-post test dilakukan uji wilxocon yang ditunjukan pada tabel 4. Berdasarkan hasil uji wilcoxon nilai p 0,001, yang berarti kurang dari 0,05 ( $p<0,05)$. Jadi bisa dikatakan bahwa kegiatan penyuluhan tentang radiasi dan upaya proteksi dapat mempengaruhi tingkat pemahaman warga Bumi mas ciseeng Blok b5/05 Kelurahan Kuripan Kecamatan Ciseeng Kab Bogor.

Tabel 3. Uji normalitas

\begin{tabular}{lll}
\hline Variabel & \multicolumn{2}{l}{ Shapiro-wilk } \\
\cline { 2 - 3 } & $\mathrm{df}$ & Sig \\
\hline Pres-test & 20 & 0,043 \\
Post-test & 20 & 0,000
\end{tabular}


Tabel 4. Uji wilcoxon

\begin{tabular}{lll}
\hline Nilai & Pre-test & Post-test \\
\hline Mean & 11,7 & 17,2 \\
Minimum & 4 & 14 \\
Maksimum & 15 & 18 \\
Standar deviasi & 2,77 & 1,19 \\
\hline Asymp Sig wilcoxon & & 0,000 \\
\hline
\end{tabular}

Proses penyuluhan atau edukasi merupakan proses yang perlu diukur keberhasilannya, maka dilakukan proses evaluasi sebelum dan setelah penyuluhan dengan menggunakan kuesioner prepost test. Tingkat pendidikan mempengaruhi tingkat pemahaman yang berkaitan dengan keluar masuknya informasi. Penelitian sebelumnya oleh suhardjo dkk, 2019. Menunjukan adanya efektifitas tingkat pendidikan dapat mempengaruhi sikap, kebiasaan dan meningkatkan pengetahuan tentang sebuah informasi dengan hasil menunjukan orang dewasa yang berumur lebih dari 20 tahun sudah mampu menerima informasi cukup baik. Alasan yang mendukung adalah semakin cukup umur, maka tingkat kematangan dan kekuatan seseorang akan lebih matang dalam berpikir dan bekerja sehingga terjadinya perkembangan kognitif. Perkembangan kognitif merupakan suatu proses genetik yaitu suatu proses yang didasarkan atas mekanisme biologis perkembangan sistem saraf. Bertambah umur seseorang, semakin baik susunan sel sarafnya dan semakin meningkat kemampuannya. Proses menuju kedewasaan akan mengalami adaptasi biologis dengan lingkungannya yang akan berdampak pada perubahan-perubahan kualitatif di dalam struktur kognitifnya (Sitam et al., 2019).

Penyuluhan merupakan kegiatan pemberian informasi untuk mengubah perilaku masyarakat. Penyuluhan salah satu strategi untuk memperoleh perubahan perilaku agar dapat meningkatkan pengetahuan, sehingga menimbulkan kesadaran dan dapat dilakukan dengan pemberian penyuluhan kepada anggota keluarga yang lainnya. Salah satu faktor yang dapat mempengaruhi derajat pengetahuan adalah umur, oleh karena merupakan salah satu faktor yang dapat menentukan kematangan berfikir bertindak maupun belajar. Pengetahuan sangat erat kaitannya dengan pendidikan dimana diharapkan seseorang dengan pendidikan tinggi, maka orang tersebut akan semakin luas pula pengetahuannya. Namun perlu ditekankan bahwa seorang yang berpendidikan rendah tidak berarti mutlak berpengetahuan rendah pula. Peningkatan pengetahuan tidak mutlak diperoleh di pendidikan formal, akan tetapi juga dapat diperoleh pada pendidikan non formal. Pengetahuan akan mempengaruhi sikap dan perilaku seseorang karena apabila pengetahuan baik maka cenderung untuk bersikap dan perilaku yang positif. Apabila sikap dan perilaku seseorang sudah baik maka akan berdampak baik juga pada keadaan kesehatannya (A. Azhari et al., 2019).

Tingkat pendidikan mempengaruhi masuknya informasi berdasarkan hasil studi Sitam dkk, 2019. Bahwa menunjukan adanya efektifitas pendidikan kesehatan pada orang tua yang dapat mempengaruhi sikap dan kebiasaan orang sehingga dapat diturunkan kepada anaknya, pengetahuan dan sikap merupakan faktor yang saling berhubungan satu dengan lainnya. Pengetahuan yang baik belum tentu diwujudkan dalam perilaku yang baik. Terbentuknya suatu perilaku baru dimulai pada domain kognitif. Subjek tahu terlebih dahulu terhadap stimulus yang berupa materi atau objek di luarnya sehingga menimbulkan pengetahuan baru pada subjek tersebut dan selanjutnya menimbulkan respons dalam bentuk sikap terhadap objek yang diketahui. Namun, seseorang dapat bertindak atau berperilaku tanpa mengetahui dahulu makna stimulus yang diterimanya. Oleh karena itu diharapkan dari penyuluhan yang telah dilakukan dapat meningkatkan 
pengetahuan sehingga dapat mempengaruhi tindakan dan sikap pada keluarga khususnya (Sitam et al., 2019).

Selain itu terkait dengan efek radiasi dosis rendah yang disebabkan oleh radiasi alam dibutuhkan pengamatan langsung dan studi efek radiobiologik dan epidemiologi radiasi pengion dari naturally occurring radioactive materials (NORM). Studi semi-epidemiologik sederhana dengan jumlah responden yang sangat terbatas telah dilakukan untuk mengevaluasi efek kesehatan. Data ini dapat digunakan sebagai data dasar dalam mengkaji dampak radiasi alam terhadap kesehatan penduduk yang merupakan data masukan dalam studi epidemiologi di masa mendatang. Selain itu data dosis ini bisa sebagai data dasar dalam mengkaji status kesehatan penduduk dalam hubungannya dengan paparan radiasi alam yang tinggi (Syaifudin, 2017). Salah satu konsep pada proteksi radiasi yang digunakan pada prinsip optimisasi proteksi untuk membatasi dosis individu disebut penghambat dosis (dose constraint). Isu tentang kajian proteksi radiasi pada lingkungan adalah berkaitan dengan paparan radiasi terhadap efek yang akan terjadi pada komponen lingkungan. Jika tujuan utama pada sistem proteksi radiasi terhadap manusia adalah mencegah terjadi efek deterministik dan membatasi kemungkinan terjadinya efek stokastik, maka ICRP memberikan rekomendasi bahwa tujuan proteksi bagi lingkungan adalah melindungi habitat, komunitas dan ekosistem dari dampak yang ditimbulkan oleh radiasi (Hiswara, 2016). Antioksidan diperlukan untuk mencegah stres oksidatif. Stres oksidatif adalah kondisi ketidak seimbangan antara jumlah radikal bebas yang ada dengan jumlah antioksidan di dalam tubuh. Radikal bebas merupakan senyawa yang mengandung satu atau lebih elektron tidak berpasangan dalam orbitalnya, sehingga bersifat sangat reaktif dan mampu mengoksidasi molekul di sekitarnya (lipid, protein, DNA, dan karbohidrat). Antioksidan bersifat sangat mudah dioksidasi, sehingga radikal bebas akan mengoksidasi antioksidan dan melindungi molekul lain dalam sel dari kerusakan akibat oksidasi oleh radikal bebas atau oksigen reaktif (Werdhasari, 2014).

\section{KESIMPULAN}

Hasil setelah penyuluhan pengetahuan warga menjadi meningkat $92 \%$ untuk indikator pengertian, pemanfaatan dan efek radiasi, sedangkan $97 \%$ untuk proteksi radiasi dengan antioksidan. Dari hasil uji wilcoxon nilai $\mathrm{p}<0,001$ oleh karena itu bisa dikatakan bahwa kegiatan penyuluhan tentang radiasi dan upaya proteksi dapat mempengaruhi tingkat pemahaman warga Bumi Mas Ciseeng Blok B5/05 Kelurahan Kuripan Kecamatan Ciseeng Kab Bogor.

\section{UCAPAN TERIMA KASIH}

Kami ucapkan terima kasih kepada ketua RT dan warga Bumi Mas Ciseeng Blok B5/05 Kelurahan Kuripan Kecamatan Ciseeng Kab Bogor, Unit Penelitian dan Pengabmas Poltekkes Kemenkes Jakarta II yang telah mendanai Kegiatan Pengabdian Kepada Masyarakat.

\section{DAFTAR PUSTAKA}

Alatas, Z. (2003). Efek Kesehatan Pajanan Radiasi Dosis Rendah. Prosiding Seminar Aspek Keselamatan Radiasi Dan Lingkungan Pada Industri Non-Nuklir, 27-39. Retrieved from https://inis.iaea.org/collection/NCLCollectionStore/_Public/42/105/42105369.pdf

Alatas, Z., Lusiyanti, Y., P, S., Ramadhani, D., L, M., \& S, V. (2012). Respon Sitogenetik Penduduk Daerah Radiasi Alam Tinggi Di Kabupaten Mamuju, Sulawesi Barat. Indonesian Journal of Nuclear Science and Technology, 13(1), 13-26.

Azhari, A., Susilo, I. R. octavia putri, \& Sitam, S. (2019). Pengetahuan Orang Tua Terhadap Antioksidan dan Radiasi Pengion Alam (Radon) pada SDN Desa Arjasari Kecamatan Arjasari 
Kabupaten Bandung. Gaster, 17(2), 119. https://doi.org/10.30787/gaster.v17i2.405

Azhari, Azhari, Susilo, I. R. O. P., Bintarsih, B., Lubis, R. F., \& Sitam, S. (2019). Dosis Rata-Rata Harian dan Efektif Tahunan Radon Airtanah pada Daerah Gunung Masigit, Kecamatan Cipatat, Kabupaten Bandung Barat, Indonesia. RISET Geologi Dan Pertambangan, 29(2), 163-170. https://doi.org/10.14203/risetgeotam2019.v29.1020

Feydri Ferdita Dera, Sri Suryani, Bualkar Abdullah, E. P. (n.d.). Gambaran Dosis Interna Dari Bioassay Sampel Urine Penduduk Desa Botteng Kabupaten Mamuju. Retrieved October 11, 2021, from https://onesearch.id/Record/IOS5831.123456789-26944

Hiswara, E. (2016). Aspek Lingkungan Pada Sistem Proteksi Radiasi. Buletin BATAN: Nuklir Mengabdi Kemanusiaan.

Hutabarat, T. (2018). Kajian Bahaya Radiasi Terhadap Norm Dalam Sedimen Evaluation Of Radiation Hazards To Norm In Sediment Surface In The Cisadane Hulu And Ciujung Hulu. Jurnal Batan, 15(1), 45-57.

Pande, M. U. (n.d.). Analisis faktor-faktor yang mempengaruhi laju paparan radiasi alam di lingkungan.

Safitri, R. A., Setiawati, E., \& Wijaya, S. (2017). Analisis Aktivitas Radionuklida Alam Dan Dosis Paparan Radiasi Pada Material Bangunan. Youngster Physics Journal, 6(1), 1-8.

Sitam, S., Putri, I. R. O., Azhari, A., Firman, R. N., Epsilawati, L., Pramanik, F., \& Yohana, W. (2019). Tingkat Pengetahuan Orang Tua Tentang Kesehatan Gigi Dan Mulut Yang Dipengaruhi Radiasi Pengion Radon Pada Kecamatan Desa Gunung Masigit Kabupaten Bandung Barat. Jurnal Pengabdian Kepada Masyarakat, 4(3), 51-54.

Syaifudin, M. (2017). Mamuju Sebagai Area Prospektif Untuk Studi Epidemiologi Dampak Paparan Radiasi Alam Tinggi. Buletin Alara, 19(1), 17-25.

Wahyudi, Syarbaini, \& Kusdiana. (2014). Pemetaan Radioaktivitas K-40, Ra-226 dan Th-232 dalam Sampel Tanah dari Pulau Bangka. Prosiding Pertemuan Dan Presentasi Ilmiah Fungsional Pengembangan Teknologi Nuklir IX, 7513906(49), 154-165.

Wahyudi, W., Kusdiana, K., Wiyono, M., \& Iskandar, D. (2019). Analisis Dosis Radiasi Alam Dari Paparan Radon Dan Radiasi Gamma Di Rumah Penduduk Di Kalimantan Barat. GANENDRA Majalah IPTEK Nuklir, 22(2), 63. https://doi.org/10.17146/gnd.2019.22.2.5094

Werdhasari, A. (2014). Peran Antioksidan Bagi Kesehatan. Jurnal Biomedik Medisiana Indonesia, $3(2), 59-68$. 